\title{
Present status of the conservation of livestock genetic resources in Brazil is
}

\author{
A. da S. Mariante ${ }^{\mathrm{a}, *}$, M. do S.M. Albuquerque ${ }^{\text {a }}$, A.A. Egito ${ }^{\text {a }}$, C. McManus ${ }^{\mathrm{b}}$, \\ M.A. Lopes ${ }^{\text {a }}$, S.R. Paiva ${ }^{\text {a }}$ \\ a Embrapa Genetic Resources and Biotechnology, C. Postal 02372 Brasília, DF, 70770-900, Brazil \\ ${ }^{\mathrm{b}}$ FAV, Universidade de Brasília, DF, 70910-900, Brazil
}

\begin{abstract}
Brazil has various species of domestic animals, which developed from breeds brought by the Portuguese settlers soon after the discovery of the country. After being submitted to a long process of natural selection, these breeds present characteristics adapted to specific Brazilian environmental conditions, and are known as "criollo", "local" or naturalized breeds. From the beginning of the 20th century, some exotic breeds, selected in temperate regions, have begun to be imported, and, although more productive, they do not have adaptive traits, such as resistance to disease and parasites found in the naturalized breeds. Even so, they gradually replaced the native breeds, to such an extent that the latter are in danger of extinction. To avoid further loss of this important genetic material, in 1983 the National Research Center for Genetic Resources and Biotechnology (Cenargen) of the Brazilian Agricultural Research Corporation (Embrapa) decided to include conservation of animal genetic resources among its priorities. The conservation activities have been conducted under the Brazilian Genetic Resources Network - Renargen, and is carried out by various research centres of Embrapa, universities and State research institutions, as well as by private farmers, with a single coordinator at national level, Cenargen. The in situ conservation of cattle, horses, buffaloes, donkeys, goats, sheep and pigs is being carried out by Conservation Nuclei, located in the animal's original habitat. Ex situ conservation is centred at the Brazilian Animal Germplasm Bank (AGB), kept at Cenargen. This is responsible for the storage of semen and embryos of various breeds of domestic animals threatened with extinction. Presently the AGB has almost 60,000 doses of semen and more than 250 embryos, as well as over 7000 DNA samples. An important challenge for this program is to increase awareness within the different segments of society in terms of the importance of the conservation of animal genetic resources. The development and evolution of Renargen and its efforts to facilitate the conservation of genetic resources of livestock in Brazil are described in this paper.
\end{abstract}

(C) 2008 Elsevier B.V. All rights reserved.

Keywords: Germplasm; Genetic diversity; Conservation Nuclei; Endangered breeds

\section{Introduction}

Most livestock are not indigenous to Brazil. Several animal species were considered domesticated in the pre-

\footnotetext{
is This paper is part of a special issue entitled Animal Genetic Resources, Guest Edited by Ricardo Cardellino.

* Corresponding author.

E-mail address: mariante@cenargen.embrapa.br (A.S. Mariante).
}

colonial period, since the indigenous people managed them in a manner typical of European livestock production. Over the last 500 years there have been periodic introductions of farm animals to Brazil, resulting in the wide range of genetic diversity that for centuries supported domestic animal production in the country. Through the process of random drift allied with natural selection, these naturalized breeds became adapted to the biotic and abiotic pressures typical of the different 
Brazilian ecosystems. From the beginning of the 20th century, some commercial breeds, selected in temperate regions, have been imported. Although more productive, most of these breeds do not have adaptive traits such as resistance to disease and parasites found in the naturalized breeds. Even so, they gradually replaced the native breeds to such an extent, that the latter are, in most cases, in danger of extinction (Mariante and Cavalcante, 2006). To avoid further loss of this important genetic material, in 1983 the National Research Center for Genetic Resources and Biotechnology of the Brazilian Agricultural Research Corporation (Embrapa) decided to include conservation of animal genetic resources among its priorities.

\section{National Research Center for Genetic Resources - Cenargen}

Since the beginning of the 1970s, there has been global concern about the need to preserve genetic resources essential for food and agriculture. In 1974 the Brazilian Government created, within the Brazilian Agricultural Research Corporation - Embrapa, a research centre whose basic mission was to coordinate the appropriate means of management of the genetic resources in the country. This unit was called National Research Center for Genetic Resources (Cenargen). In 1984, this unit also incorporated research activities using biotechnology aimed at the conservation and use of genetic resources, becoming the Genetic Resources and Biotechnology Centre of the Embrapa Network (Mariante et al., 2003b).

The Genetic Resources and Biotechnology Centre is a thematic research centre of Embrapa whose main objectives are to conserve and characterize genetic resources (plants, animals and micro-organisms), as well as to develop information and technologies in Advanced Biotechnology, Biological Control and Biological Security. With the consolidation of the National System of Agricultural Research in Brazil, including 40 Embrapa research centres, State agricultural research institutions as well as universities, an environment was established for the development of a National Network of Genetic Resources.

\section{National Network of Genetic Resources — Renargen}

The creation of the National Network of Genetic Resources - Renargen, helped to organize and increase the efficiency of activities such as collection, exchange and quarantine, characterization, evaluation, documentation, and most importantly, conservation of germplasm critical to support research in food and agriculture in the country.

Renargen has also provided key support for the tremendous technological advances obtained by Brazilian agriculture over the last three decades, enabling the R\&D system to incorporate and utilize genetic resources for development of plant cultivars, breeds of animals and strains of micro-organisms of importance to the agroindustry and agro-food sectors in the country. Also, the network has made significant efforts to raise the awareness of the Brazilian society with regard to the strategic importance of genetic resources and biodiversity for the country's future. Considerable effort has been made to conserve and promote the sustainable use of native plants and naturalized animals of economic interest, as well as to consolidate in situ and on-farm conservation strategies. This has created the basis for increasing income, food sufficiency and the aggregation of environmental and social values to traditional communities dependent on biodiversity (Mariante and Cavalcante, 2006; Mariante et al., 2003b; Mariante and Egito, 2002).

The major activities of this network are the following: (a) enrichment: germplasm collection, introduction, exchange and quarantine; (b) conservation: in situ (either in nature or on-farm) and ex situ (seeds in cold storage; explants in vitro, micro-organisms culture; cryopreservation of semen, embryos and oocytes); (c) characterization: phenotypic and genetic; and (d) information. The network maintains a Curatorship System and an Information System called Sibrargen (Brazilian Information System for Genetic Resources). Renargen is made up of eleven research projects. Among them, one deals specifically with the conservation and utilization of livestock genetic resources.

\section{Conservation of livestock genetic resources in the Renargen Network}

Embrapa's Genetic Resources and Biotechnology Centre has an animal genetic resources research team specialized in conservation per se, genetic characterization and animal reproduction, that coordinates the strategy of conservation of livestock genetic resources within Renargen. This team runs an Animal Germplasm Bank, located at the Sucupira Experimental Farm, a 1800 hectares property, and located approximately $30 \mathrm{~km}$ from the base unit. The Animal Genetics Laboratory, three Animal Reproduction Laboratories and a modern Genome Laboratory, complete the infrastructure (Mariante et al., 2000).

The objectives of this component of Renargen include the following: (a) identification of populations in advanced state of genetic dilution; (b) phenotypic and genetic characterization of germplasm; and (c) evaluation of production potential. Conservation is carried out in nucleus herds (Conservation Nuclei), maintained in the habitats where the animals have been naturally selected (in situ), 
and embryo and semen storage (ex situ) is carried out by the Animal Germplasm Bank (AGB), on the Sucupira Experimental Farm. The Conservation Nuclei, organized in the form of individual research projects, are located all over the country. These are usually based in research centres, and aim to rescue the small effective populations of the breeds in danger of extinction. These Conservation Nuclei are distributed in ten Action Plans within Renargen, presented in Table 1.

The articulation between the Conservation Nuclei and the Genetic Resources and Biotechnology Centre is carried out by the Germplasm Curator (researchers of Cenargen) and the Curators of the Germplasm Banks (leaders of research projects located in diverse research centres). In the present structure, there are two curators for animals in the Genetic Resources and Biotechnology Centre: one for large livestock species (cattle, buffaloes, horses and donkeys) and one for small livestock species (sheep, goats and pigs) (Mariante et al., 2000, 2003a).

The Germplasm Curators work at national and international levels, specifically with the enrichment of knowledge and conservation of germplasm. Among other functions, they promote, start and continue activities related to conservation, multiplication and/or regeneration of germplasm of species under their responsibility, while the Curators of the Germplasm Banks have the responsibility to maintain the Conservation Nucleus under their responsibility, as well as to multiply, regenerate and distribute the germplasm. The species and breeds included in the Brazilian Conservation Program are shown in Table 2 and their geographical distribution is shown in Fig. 1.

\subsection{Animal Germplasm Bank}

As stated above, in 1983 Cenargen decided to include conservation of animal genetic resources in its research program "Conservation and Utilization of Genetic Re-

Table 1

Action plans of the project "collection, characterization and ex situ conservation of livestock animal germplasm"

\begin{tabular}{ll}
\hline No. & Action plan \\
\hline 1 & Identification of animal populations and their long term conservation \\
2 & Genetic characterization of animal germplasm \\
3 & Conservation Nuclei for goats \\
4 & Conservation Nuclei for hair sheep \\
5 & Conservation Nuclei for animal genetic resources of the Amazon \\
6 & Conservation Nuclei for animal genetic resources in the Pantanal \\
7 & Conservation Nuclei for animal genetic resources in the Mid North \\
8 & Conservation of animal genetic resources in the Southern fields \\
9 & Conservation Nuclei for animal genetic resources of the Lavrado \\
10 & Conservation Nuclei for swine and poultry genetic resources \\
\hline
\end{tabular}

Table 2

Species and breeds included in research projects in the Brazilian Program of Livestock Genetic Resources Conservation — 2008

\begin{tabular}{|c|c|c|}
\hline Species & Breed & Region of the country \\
\hline \multirow[t]{6}{*}{ Cattle } & Caracu & South/southeast \\
\hline & Criollo Lageano & South \\
\hline & Curraleiro or Pé-duro & Northeast/central-west \\
\hline & Junqueira & Southeast \\
\hline & Mocho Nacional & Southeast \\
\hline & Pantaneiro & Central-west (Pantanal) \\
\hline \multirow[t]{2}{*}{ Buffaloes } & Baio & North \\
\hline & Carabao & North \\
\hline \multirow[t]{2}{*}{ Donkeys } & Northeastern donkey & Northeast \\
\hline & Brazilian donkey & Southeast \\
\hline \multirow[t]{5}{*}{ Goats } & Azul & Northeast \\
\hline & Canindé & Northeast \\
\hline & Marota & Northeast \\
\hline & Moxotó & Northeast \\
\hline & Repartida & Northeast \\
\hline \multirow[t]{6}{*}{ Horses } & Baixadeiro & Northeast \\
\hline & Campeiro & South \\
\hline & Lavradeiro & North \\
\hline & Marajoara & North \\
\hline & Pantaneiro & Central-west (Pantanal) \\
\hline & Puruca & North \\
\hline \multirow[t]{3}{*}{ Pigs } & Monteiro & Central-west (Pantanal) \\
\hline & Moura & South \\
\hline & Piau & Southeast/northeast \\
\hline \multirow[t]{7}{*}{ Sheep } & Blackbelly & North \\
\hline & Brazilian Bergamasca & Central-west/southeast \\
\hline & Brazilian Somali & Northeast \\
\hline & Criollo Lanado & South \\
\hline & Fat Tail & Northeast \\
\hline & Morada Nova & Northeast \\
\hline & Santa Inês & All regions \\
\hline
\end{tabular}

sources", which until then only contemplated plants. One of the reasons why animals were included in the Conservation Program was that the entire surviving population of the Mocho Nacional cattle breed entire surviving population consisted of three bulls and eight cows, found in the State of São Paulo. Two veterinarians were immediately hired and began to collect semen and embryos. It was perhaps fortunate, that this breed had a small number of individuals for successful multiplication. Also, it was the only Brazilian criollo cattle breed that possessed the polled gene, a dominant and useful genetic trait.

The reproduction team working on conservation of animal genetic resources increased and started to develop new techniques. Two laboratories were then established: one for the development of these new techniques utilizing the mouse as a biological model, and another to apply the developed techniques on livestock on Cenargen's Experimental Farm. Techniques on collection and freezing semen on-farm, collection of embryos (surgically at the beginning), as well as freezing thawing and transferring them to recipient cows, micro-manipulation of embryos, 
permitting the production of identical twins from a single embryo, were successfully developed. More recently, in vitro fertilization and cloning were also developed in these laboratories. Semen and embryos from cattle, horses, buffaloes, donkeys, goats, sheep and pigs are being stored at the Animal Germplasm Bank (AGB), that presently holds almost 60,000 doses of semen and more than 250 embryos.

The creation of the Animal Genetics Laboratory (AGL) at the Genetic Resources and Biotechnology Centre led to studies on genetic characterization of the species included in Renargen. A DNA bank was formed for this purpose, with samples extracted from blood, semen and hair. At present there are more than 7000 DNA samples from different populations, including commercial breeds used as outgroups, as well as some wildlife species with agricultural potential (the rodent capybara and two species of wild hogs). Immortal tissue and cell samples have also been included, which will serve as eternal sources for future characterization studies, in the search for molecular markers linked to production traits, as well as for the use in biotechnological studies.

New populations of endangered native breeds are constantly being identified. Some of them are very similar to breeds officially included in the in situ conservation program, while others have totally distinct characters. In general, these new populations found have very small numbers, and the first strategy has been to include them in the cryopreservation program. This assures the storage of genetic material in the Animal Gene Bank (AGB) in Cenargen. At the same time, their blood is collected to be used for genetic characterization.

\subsection{Genetic diversity}

Animal domestication began approximately 12,000 years ago and since then a large group of subpopulations has developed. This was a function of the adaptation of the different animal species to different environmental conditions when they accompanied man during his migration into new territories. The existing variance between these subpopulations, called breeds, and the variance within each of them, represent the genetic diversity found in domestic breeds.

Despite some naturalized breeds having different names and inhabiting different regions, they show similar phenotypes. This fact raises doubts about their identity as a distinctive breed group or native type. These geographically separate populations may or may not be genetically similar. Even if they belong to the same breed, due to geographical isolation or their adaptation to different ecological niches, they may have accumulated different alleles due to genetic drift. Therefore, genetic characterization would permit the identification of these unique genetic groups which were isolated in their environment for a long time.

Since a complete description of the differences between two breeds/populations is not viable, the first step in the genetic characterization of naturalized breeds is to test the genetic structure of these populations. Gibson and Bishop (2005) pointed out that, in the short term, molecular marker information provides the most easily obtainable estimates of the genetic diversity within and between a given set of breeds. The genetic difference between the populations is one of the criteria that may be used when deciding which populations should be conserved. This is especially important when resources are scarce, thereby avoiding the duplication of efforts in maintenance of samples of breeds. On the other hand, it ensures the maintenance of genetic variability, avoiding the culling of populations of the same breed which have particular characteristics, during the conservation process. The final choice of breeds and individuals to be conserved should take into consideration all information on: (a) traits of economic interest; (b) adaptation characteristics; and (c) presence of unique alleles.

For a long time the characterization of different breeds of domestic animals in Brazil was based, almost exclusively, on phenotypic data (morphology and production). This is sometimes insufficient to distinguish between pure breeds and is heavily influenced by environmental factors. However, since 1998 the genetic diversity of the main species of livestock has been estimated using different molecular markers, such as: mitochondrial (Egito et al., 2006), Y-chromosome (Paiva et al., 2006) as well as RAPDs (Spritze et al., 2003; Serrano et al., 2004; Oliveira et al., 2005; Paiva et al., 2005a,b; Albuquerque et al., 2006a) and microsatellites (Paiva et al., 2005a,b; Albuquerque et al., 2006b; Menezes et al., 2006; Araújo et al., 2006).

Table 3 shows a summary of the genetic diversity observed in five livestock species in Brazil, obtained using microsatellite markers at the Animal Genetics Laboratory of Cenargen. Although they show individual, breed and loci variations, four of the five species analysed showed similar inter-breed variation, except for the swine. The lowest indices of genetic diversity (He and MNA) were observed for buffaloes and pigs. The highest inbreeding values $\left(F_{\text {IS }}\right)$ were observed in horses and buffaloes. These patterns may be explained by the recent introduction of buffaloes into Brazil and by the low effective population size, as well as the low number of stallions used for reproduction in the equine breeds. Of all the species analysed, the naturalized pig 


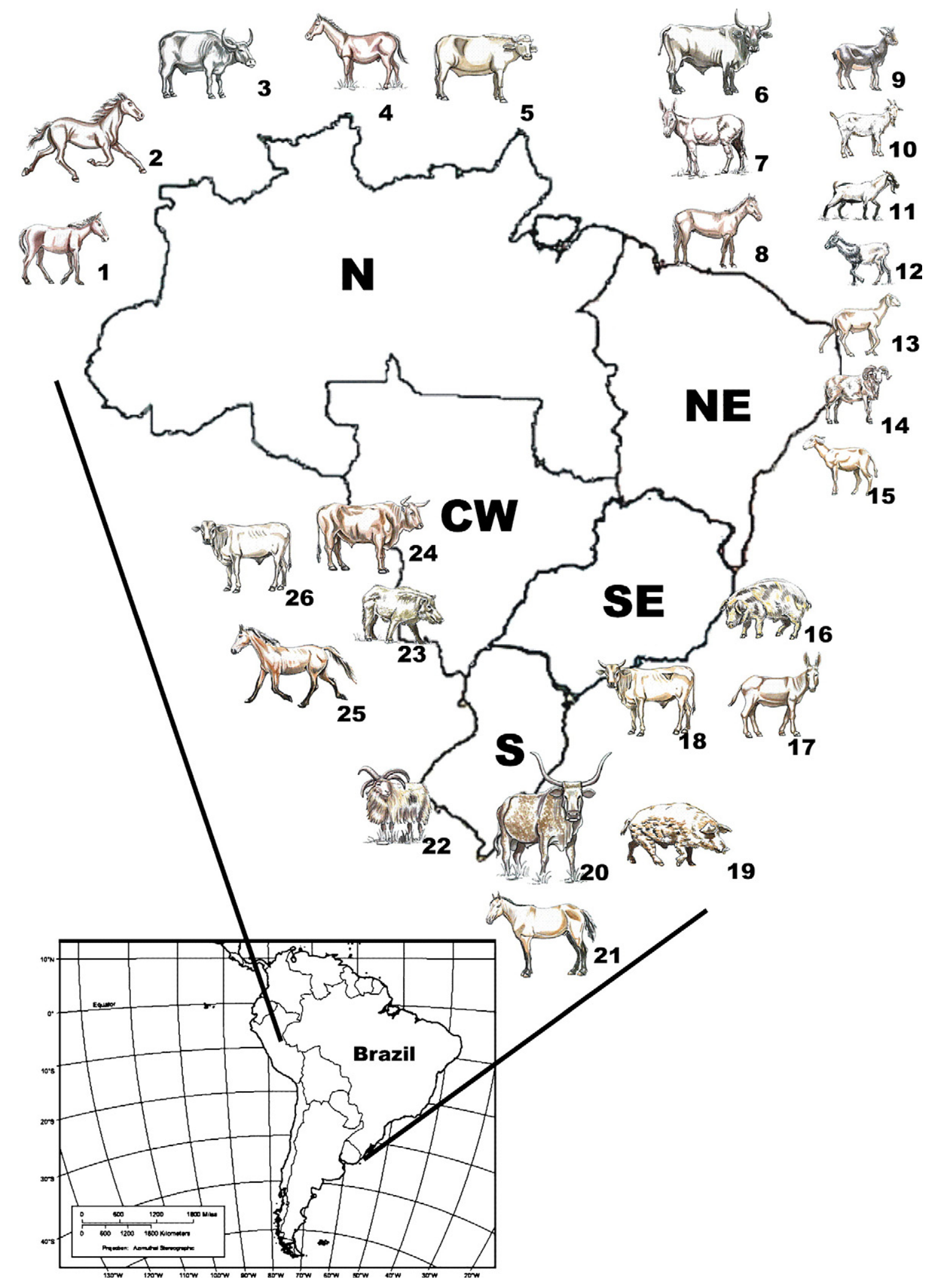


Table 3

Genetic diversity of five livestock species with microsatellite markers

\begin{tabular}{llllllll}
\hline Species & $N$ & NB (local breeds) & Number loci & He & MNA & FIS & AMOVA (\%) \\
\hline Buffaloes & 382 & 05 & 14 & 0.686 & 10.07 & 0.224 & $11.91^{*}$ \\
Cattle & 915 & $10(8)$ & 22 & 0.816 & 13.18 & 0.167 & 11.87 \\
Horses & 328 & $07(05)$ & 11 & 0.875 & 14.36 & 0.204 & $12.37^{*}$ \\
Sheep & 383 & $10(05)$ & 19 & 0.775 & 10.84 & 0.015 & $11.76^{*}$ \\
Pigs & 182 & $05(03)$ & 24 & 0.702 & 10 & 0.114 & $15.73^{*}$ \\
\hline
\end{tabular}

$N$ is the number of individuals; NB is number of breeds; He is expected heterozygosis; MNA is mean number of alleles; $F_{\mathrm{IS}}$ is inbreeding index; AMOVA is Analysis of Molecular Variance between breeds.

${ }^{*} p<0.001$.

breeds are the most threatened by extinction in Brazil. Another pattern not shown specifically in Table 3, but which emphasizes the strategic importance of naturalized breeds, was that, within each species, these breeds present a higher diversity values than the commercial breeds, showing that the conservation programme is moving in the right direction.

Along with the discovery of the basic genetic diversity distribution within and between these breeds using neutral markers, it is important to note that studies have begun on the identification of SNPs (single nucleotide polymorphisms) in genes of economic interest (e.g. Castro et al., 2006), as well as the development of mapping studies and markers associated linked to production traits (Faria et al., 2006). Studies with species such as donkeys and goats, utilizing the same molecular markers are already under way.

\section{Capacity building efforts - link between research and education}

Over the years, various international courses have been offered in Embrapa within the framework of the animal genetic resources component of Renargen. Many of these courses were offered in partnership with FAO. There is also a growing demand for technical courses on embryo transfer and in vitro fertilization, which are offered each year, reflecting the interest of the research community and farmers in using the technologies generated by the network (Mariante et al., 2003a).

Due to a close partnership with the University of Brasilia (UnB), a capacity building effort has been developed, with two main lines of research at master's level offered together with the Genetic Resources and
Biotechnology Centre: one with emphasis on characterization and conservation of animal genetic resources and the other on animal reproduction strategies. This collaboration has been fundamental for recent advances in the conservation and characterization of animal genetic resources in Brazil. To date, 40 Master's dissertations have been completed due to this partnership. These dissertations deal in general with topics associated with quantitative genetics (18 dissertations mainly on sheep, cattle, buffaloes and horses), molecular genetics (6 dissertations on these same species) and reproduction (16 dissertations). This has meant that there is now information on production parameters for the Pantaneiro (Miserani et al., 2002) and Campeiro (McManus et al., 2005a) horses, Buffaloes (Cassiano et al., 2004), Pantaneiro (McManus et al., 2002; Abreu et al., 2002) and Mocho Nacional (McManus et al., 2005b) cattle, Morada Nova (Quesada et al., 2002), Santa Inês and Brazilian Bergamasca sheep (McManus et al., 2003), heat tolerance measures for five Brazilian breeds of cattle and three breeds of sheep (Prescott, 2004; Oliveira, 2005), as well as genetic distances between the main breeds of cattle (Spritze et al., 2003; Serrano et al., 2004; Egito et al., 2005), buffaloes (Albuquerque et al., 2005), sheep (Paiva et al., 2004), goats (Oliveira et al., 2005), horses (Fuck, 2002; Silva et al., 2005) and pigs (Mariante et al., 2003a; Sollero, 2006). The success of this programme has led to the implantation of a Ph.D. in Animal Science where the responsibility lies with the University of Brasília jointly with Embrapa Genetic Resources and Biotechnology.

These and other studies were also carried out with the help of students on study scholarships to the Genetic Resources and Biotechnology Centre or universities and researchers from the Centre doing their doctor's theses

Fig. 1. Map of the Brazilian regions and geographical distribution of the main naturalized breeds. North: 1) Marajoara horse; 2) Lavradeiro horse; 3) Carabao buffalo; 4) Puruca horse; 5) Baio buffalo. Northeast: 6) Curraleiro cattle; 7) Northeast donkey; 8) Baixadeiro horse; 9) Canindé goat; 10) Marota goat; 11) Moxotó goat; 12) Repartida goat; 13) Santa Inês sheep; 14) Fat Tail sheep; 15) Morada Nova sheep. Southeast: 16) Piau pig; 17) Brazilian donkey; 18) Caracu cattle. South: 19) Moura pig; 20) Crioulo Lageano cattle; 21) Campeiro horse; 22) Crioulo Lanado sheep. Central-west: 23) Monteiro pig; 24) Pantaneiro cattle; 25) Pantaneiro horse; 26) Mocho Nacional cattle. 
in other Brazilian universities. Many samples and data were collected by researchers in different research centres of Embrapa, as well as in State and Federal research institutions. These relationships have also led to an increased participation of all involved in publication at national and international levels in congresses, books and scientific papers. International cooperation has also increased with funding from CNPq (Brazilian National Research Council) for projects with other countries in South America (Prosul - Uruguay and Colombia) as well as projects with universities and research centres on the Iberian Peninsula.

Despite the increase in information over the last five years, much has yet to be done. Funding is limited as usually it is disputed with all other areas and the number of researchers involved is low but increasing. The student workforce has been vital for the success of the process in recent years. It would be very irresponsible to suppose that after graduation these students would continue actively working in animal conservation. The job opportunities are extremely limited in this area and efforts are made to show that the use of this knowledge is not confined to a conservation framework. In this way, the students have a wider knowledge of animal genetics themes, have contributed to the conservation knowledge and have acquired techniques for use in their professional work after graduation. The fact that these students also have been exposed to this type of work would hopefully also mean that if in the future they were confronted with a situation involving conservation issues they would be better equipped on how to resolve the problem in a more effective way.

\section{Trends and challenges to the conservation and use of livestock genetic resources in Brazil}

\subsection{Valuing and promoting strategic resources for the future}

It is important to emphasize that the Brazilian Program for the Conservation of animal genetic resources is meeting its objectives, conserving in situ and ex situ valuable genetic material, characterizing it genetically and revealing its importance to the various segments of society (Mariante, 1993). The preservation of the Brazilian naturalized breeds has its historical side, which is the "genetic memory" of animals that helped to colonize the country. In a more or less intensive form, there are still remains of all of these breeds, through their crossbreds. If these breeds were able to overcome, after dozens of generations of natural selection, the environmental challenges to which they were subjected, it is because they unite genotypes compatible with the most diverse conditions. Also, man's intervention in their reproductive and selection processes was, at most, modest and did not cause any appreciable modification in their potential, other than those received from nature. Another aspect, which deserves consideration, is in relation to the proper dynamics of natural selection, which turns these native germplasm into authentic genetic reserves, especially when selection provokes the exhaustion of additive genetic variation and there is no more response in the animal breeding programs (Pereira, 1996).

\subsection{Networking and strengthening national $R \& D$ capacity}

Conservation and promotion of the sustainable use of livestock genetic resources have to be understood as part of a complex process. Complementarities, mix of technologies and capabilities, together with effective approaches to networking must be viewed as key ingredients in developing this process. One of the key problems limiting the effective implementation of a complex process is the difficulty to build effective teams and networks (Lopes, 2000). Approaches to networking and partnerships have become important means of enabling organizations attain otherwise unattainable goals, add value to their products and processes and reduce costs. Also, the demand for efficiency and relevance presses $R \& D$ programs to move in the direction of cooperation efforts. For example, modern biotechnology cannot be considered an end in itself or a tool detached from the complexities of the use and conservation of genetic resources or from breeding strategies. It has to be understood and analysed in the context of an interacting mix of tools and strategies that have to be targeted towards crop and livestock improvement in a coordinated manner. The need for an expanded networking approach to breeding and biotechnological research will always be an objective to be pursued.

\section{Fine tuning: the need for priority setting and systematic connection to future innovation strategies}

For many reasons, developing countries do not put conservation of livestock genetic resources as a priority, mainly because their main goals are increased production and competitiveness in the global market in the short term. Brazil is one of the countries in this situation. Future configuration of domestic animal genetic resources and breeding programs is dependent on knowledge to guide strategic decisions about structures, methods, and capacities in order to take advantage of new opportunities and technological niches that can benefit from strong programs in the use and conservation of genetic resources. 
Unfortunately, there are very few prospective efforts directed to thinking about the future of genetic resources and breeding programs, especially in developing countries. Research organizations need information that is not currently available, about the changes and influences and their impact in the future of key activities (Lima et al., 2005). To obtain and organize this information, prospective studies on the present and future performance of genetic resources and breeding programs and their related activities will have to be systematically developed in the country. These prospective studies and priority setting mechanisms, together with cost benefit analysis will be valuable to guide informed decisions on how to organize and manage future livestock genetic resources and breeding programs in Brazil.

\section{References}

Abreu, U.G.P., McManus, C., Moreno-Bernal, F.E., Lara, M.A.C., Sereno, J.R.B., 2002. Genetic and environmental factors influencing birth and 205-day weight of Pantaneiro calves. Arch. Zootec. 51, 83-89.

Albuquerque, M.S.M., Egito, A.A., Paiva, S.R., Marques, J.R.F., Mariante, A.S., Ciampi, A.Y., Faria, D.A., Castro, S.T.R., Costa, M.R., Caetano, A.R., Silva, A.C.M., Contel, E.P.B., 2005. Marcadores moleculares e variabilidade genética em búfalos no Brasil., Mem. VI Simp. Iberoamer. Conserv. Utiliz. Rec. Genét., pp. 173-175.

Albuquerque, M.S.M., Egito, A.A., Marques, J.R.F., Ciampi, A.Y., Mariante, A.S., Castro, S.T.R., Costa, M.R., Paiva, S.R., Silva, A.C.M., Contel, E.P.B., 2006a. Variabilidade genética em búfalos determinada por marcadores RAPD. Pesqui. Agropec. Bras. 41, 621-628.

Albuquerque, M.S.M., Paiva, S.R., Egito, A.A., Marques, J.R.F., Faria, D.A., Mariante, A.S., Castro, S.T.R., Ciampi, A.Y., Caetano, A., Contel, E.P.B., 2006b. Population structure of buffaloes in Brazil using microsatellite markers. Proc. 30th Intern. Conf. on Anim. Genet. - ISAG, 2006, Porto Seguro, Brazil. 4 pp., CD-ROM.

Araújo, A.M., Guimarães, S.E.F., Machado, T.M.M., Lopes, P.S., Pereira, C.S., Silva, F.L.R., Rodrigues, M.T., Columbiano, V.S., Fonseca, C.G., 2006. Genetic diversity between herds of Alpine and Saanen dairy goats and the naturalized Brazilian Moxotó breed. Genet. Mol. Biol. 29 (1), 67-74.

Cassiano, L.A.P., Mariante, A.S., McManus, C., Marques, J.R.F., Costa, N.A., 2004. Parâmetros genéticos das características produtivas e reprodutivas de búfalos na Amazônia brasileira. Pesqui. Agropec. Bras. 39, 451-457.

Castro, E.A., Lim, A., Lopez, I.M.R., Franco, M.M., Paiva, S.R., Souza, C.J.H., Rumpf, R., Melo, E.O., 2006. Characterization of a new SNP in the growth and differentiation factor 9 (GDF-9) gene, specific for the Brazilian Santa Inês sheep. Proc. 8th World Congr. on Genet. Appl. to Livest. Prod., Belo Horizonte, Brazil. 4 pp., CD-ROM.

Egito, A.A., Serrano, G.M.S., McManus, C., Paiva, S.R., Albuquerque, M.S.M., Castro, S.T.R., Mariante, A.S., Grattapaglia, D., 2005. Distâncias genéticas entre raças locais bovinas brasileiras estimadas com marcadores RAPD e microssatélites. Mem. VI Simp.Iberoamer. Conserv. Utiliz. Rec. Genét., San Cristobal de las Casas, México, pp. 179-181.

Egito, A.A., Albuquerque, M.S.M., Paiva, S.R., Castro, S.T.R., Mariante, A.S., 2006. Genetic characterization, In: Embrapa (Ed.), Animals of the Discovery: Domestic Animals in the History of Brazil, 2nd ed., pp. 222-253. Brazil.

Faria, D.A., Guimarães, S.E.F., Lopes, P.S., Pires, A.V., Paiva, S.R., Sollero, B.P., Wenceslau, A.A., 2006. Association between G316A growth hormone polymorphism and economic traits in pigs. Genet. Mol. Biol. 29 (4), 634-640.

Fuck, B.H., 2002. Caracterização genética do cavalo Pantaneiro: Uma contribuição para a conservação da raça. M.Sc. Thesis, University of Brasília, Brazil. 64 pp.

Gibson, J.P., Bishop, S.C., 2005. Use of molecular markers to enhance resistance of livestock to disease: a global approach. Rev. Sci. Tech. - Off. Int. Epizoot. 24 (1), 343-353.

Lima, S.M.V., de Castro, A.M.G., Machado, M. dos S., dos Santos, N.A., Lopes, M.A., de Carvalho, J.R.P., de Freitas, M.P.C., Silva, J. de S., Coelho, A.C.F., Lins, M.S.C., Martins, M.A.G., 2005. Embrapa (Ed.), Brazil, $451 \mathrm{pp}$.

Lopes, M.A., 2000. Proc. Int. Workshop Embrapa/IDB/World Bank, Brasilia Brazil, pp. 219-230.

Mariante, A.S., 1993. Conservação de recursos genéticos animais: uma questão de bom senso. Anais Simp. Conserv, 30 a Reunião Anual da Soc. Bras. Zootec., Rio de Janeiro, Brasil, pp. 175-182.

Mariante, A.S., Egito, A.A., 2002. Animal genetic resources in Brazil: result of five centuries of natural selection. Theriogenology 57, 223-235.

Mariante, A.S., Cavalcante, N., 2006. In: Embrapa (Ed.), Animals of the Discovery: Domestic Breeds in the History of Brazil, 2nd ed. Brazil, 274 pp.

Mariante, A.S., Castro, S.T.R., Wetzel, M.M.V., 2000. Conservation of animal genetic resources: structure of the Brazilian network. Proc. 5th Global Conf. Conserv. Dom. An. Genet. Res., Brasília, Brazil. 5 pp, CD-ROM.

Mariante, A.S., Castro, S.T.R., Albuquerque, M.S.M., Paiva, S.R., Germano, J.L., 2003a. Pig biodiversity in Brazil. Arch. Zootec. 52, 245-248.

Mariante, A.S., McManus, C.M., Mendonça, J.F., 2003b. Country report on the state of animal genetic resources: Brazil. Embrapa Genetic Resources and Biotechnology, Brasilia, Embrapa (Ed.). 94 pp.

McManus, C., Abreu, U.G.P., Lara, M.A., Sereno, J.R.B., 2002. Genetic and environmental factors which influence weight and reproduction parameters in Pantaneiro cattle in Brazil. Arch. Zootec. 51, 91-97.

McManus, C., Evangelista, C., Fernandes, L.A.C., Miranda, R.M., Moreno-Bernal, F.E., Santos, N.R., Louvandini, H., 2003. Curvas de crescimento de ovinos Bergamácia criados no Distrito Federal. Rev. Bras. Zootec. 32, 1202-1207.

McManus, C.M., Falcão, R.A., Spritze, A., Costa, D., Louvandini, H., Dias, L.T., Teixeira, R.A., Rezende, M.J.M., Garcia, J.A.S., 2005a. Caracterização morfológica de eqüinos da raça Campeiro. Rev. Bras. Zootec. 34, 1553-1562.

McManus, C., Ribeiro, R., Mariante, A.S., Egito, A.A., Louvandini, H., Paiva, S.R., 2005b. Aspectos de produção de rebanho da raça Mocho Nacional. Arch. Zootec. 54, 459-464.

Menezes, M.P.C., Martinez, A.M., Ribeiro, M.N., Pimenta Filho, E.C., Bermejo, J.V.D., 2006. Caracterização genética de raças caprinas nativas brasileiras utilizando-se 27 marcadores microssatélites. Rev. Bras. Zootec. 35 (4), 1336-1341.

Miserani, M., McManus, C.M., Mariante, A.S., Silva, J., Santos, S.A., Abreu, U.G.P., 2002. Avaliação de fatores que influem nas medidas lineares do cavalo Pantaneiro. Rev. Bras. Zootec. 31, 335-341.

Oliveira, E.B., 2005. Avaliação de alguns fatores físicos na adaptação ao calor em cinco raças de bovinos naturalizados brasileiros e duas de exploração comercial. M.Sc. Thesis, University of Brasília, Brazil, 61 pp. 
Oliveira, R.R., Egito, A.A., Ribeiro, M.N., Mariante, A.S., 2005. Genetic characterization of the Moxotó goat breed using RAPD markers. Pesqui. Agropec. Bras. 40 (3), 233-239.

Paiva, S.R., Faria, D.A., Silvério, V.C., McManus, C., Egito, A.A., Dergam, J.A., Guimarães, S.E.F., Castro, S.T.R., Albuquerque, M.S.M., Mariante, A.S., 2004. Relações filogenéticas entre raças de ovinos naturalizados do Brasil. Mem. V Simp. Iberoam. Conserv. Utiliz. Rec. Genét., Puno, Peru, pp. 81-83.

Paiva, S.R., Faria, D.A., Silvério, V.C., McManus, C., Egito, A.A., Dergam, J.A., Guimarães, S.E.F., Castro, S.T.R., Albuquerque, M.S.M., Mariante, A.S., 2005a. Genetic variability among Brazilian sheep using microsatellites. Proc. The Role of Biotech. for the Character. of Crop, Forestry Anim. and Fish. Genet. Res., Turim. Italy, pp. 195-196.

Paiva, S.R., Silvério, V.C., Egito, A.A., McManus, C.M., Faria, D.A., Mariante, A.S., Castro, S.T.R., Albuquerque, M.S.M., Dergam, J.A., 2005b. Genetic variability of the main Brazilian hair sheep breeds using RAPD-PCR markers and conservation implications. Pesqui. Agropec. Bras. 40, 887-893.

Paiva, S.R., Dias, C., Faria, D.A., McManus, C.M., Oliveira, A.A., Lobo, R.N.B., Sousa, W.H., Dergam, J.A., Albuquerque, M.S.M., Mariante, A.S., 2006. Y-chromosome variability of Brazilian sheep breeds. Proc. 8th World Congr. Genet. Appl. to Livest. Prod., Belo Horizonte, Brazil. 4 pp., CD-ROM.
Pereira, J.C.C., 1996. Melhoramento genético aplicado à produção animal. Belo Horizonte. 416 pp.

Prescott, E., 2004. Análise comparativa da tolerância ao calor de raças bovinas naturalizadas brasileiras com base em parâmetros fisiológicos. M.Sc. Thesis. University of Brasília, Brazil, 66 pp.

Quesada, M., McManus, C.M., Couto, F.A.D., 2002. Efeitos genéticos e fenotípicos sobre características de produção e reprodução de ovinos deslanados no Distrito Federal. Rev. Bras. Zootec. 31, 342-349.

Serrano, G.M.S., Egito, A.A., McManus, C., Mariante, A.S., 2004. Genetic diversity and population structure of Brazilian native bovine breeds based on RAPD markers. Pesqui. Agropec. Bras. 29, 543-549.

Silva, A.C., Paiva, S.R., Albuquerque, M.S.M., Egito, A.A., Faria, D.A., Castro, S.T.R., Mariante, A.S., Santos, S.A., McManus, C., 2005. Distâncias genéticas entre raças de eqüinos naturalizadas brasileiras. Mem. VI Simp. Iberoam. Conserv. Utiliz. Rec. Genét. 5 pp, CD-ROM.

Sollero, B.P., 2006. Diversidade genética das raças naturalizadas de suínos no Brasil, por meio de marcadores microssatélites. M.Sc. Thesis. University of Brasília, Brazil, 66 pp.

Spritze, A., Egito, A.A., Mariante, A.S., 2003. Caracterização genética da raça bovina Crioulo Lageano usando marcadores moleculares RAPD. Pesqui. Agropec. Bras. 38, 1157-1164. 